\title{
Advances in Sport and Performance Nutrition
}

\author{
Antonio Paoli 1,2,3 (D) \\ 1 Department of Biomedical Sciences, University of Padova, 35131 Padova, Italy; antonio.paoli@unipd.it \\ Faculty of Sport Sciences, UCAM, Catholic University of Murcia, 30107 Murcia, Spain \\ European Sport Nutrition Society, 43126 Parma, Italy
}

Received: 27 February 2019; Accepted: 1 March 2019; Published: 2 March 2019

check for updates

This monograph "Advances in Sport and Performance Nutrition" collects 12 papers from several countries, from Australia to Thailand, of which 10 are original researches and two are reviews. This volume confirms the fact that sport nutrition is a wide and multifaceted field of investigation. One emerging topic in sport nutrition and also in general human nutrition is the "deep sea" of microbioma research. In this volume, Mortaza and colleagues investigate the effects of a period of intensified endurance training during a high-carbohydrate diet or very low-carbohydrate ketogenic diet. The effects of a ketogenic diet on sport performance is a controversial topic [1]. The results of Mortaza and colleagues suggest that a low-carbohydrate, high-fat ketogenic diet influences the relative abundances of some key bacterial taxa, with an increase of Bacteriodes that paradoxically correlates with fat oxidation [2]. The amount and the type of carbohydrates (i.e., low glycemic index versus high glycemic index [3]) in sport nutrition has been an important field of investigation in the last decades. The novelty of the paper of Vlahoyiannis and co-workers [4] is the focus on the effects of the high or low glycemic index of a post-exercise meal on another "hot" topic in sport and performance: the quality of sleep. They suggested that a high glycemic index meal, following a single spring interval training session, can improve both sleep duration and sleep efficiency, while reducing in parallel sleep onset latency. One of the oldest supplements used for the legal improvement of sport performance is sodium bicarbonate $\left(\mathrm{NaHCO}_{3}\right)$. From the seminal paper of the Harvard Fatigue Laboratory [5], through the more $\mathrm{NaHCO}_{3}$-focused works of Jones and colleagues [6] to the very last papers published, the right dosage and timing of $\mathrm{NaHCO}_{3}$ supplementation and its combination with other molecules $[7,8]$ is a very important topic for sport nutrition. The overall small but positive effects $(2-3 \%)$ on different performance outcomes [9] vindicate the ever-present attention to this supplement.

One of the main issues for athletes and coaches is recovery. Often unrecognized, recovery is however a fundamental part of every training program. There are many factors affecting recovery [10], and appropriate nutrition is one of the most important. In this field, so-called "functional beverages" could play a role [11] together with other supplements, such as omega 3. It is well known that omega 3 plays a fundamental role in reducing physiological inflammation [12] through resolvins [13], and its utility for muscle damage and recovery in sports has been widely demonstrated [14]. Also, many other supplements have been advocated to be helpful for athletes' recovery strategies (antioxidant-rich foods, creatine, curcumin, etc.). Above all, quercetin deserves more attention; for example, it has been demonstrated to exert a cardioprotective effect on mdx mice [15]. In this special issue, Bazzucchi and colleagues demonstrated that quercetin supplementation attenuates the severity of muscle weakness caused by eccentrically-induced muscle damage [16]. Also, protein intake is critical for muscle recovery after exercise. Protein supplementation is the most-used supplement among athletes and gym enthusiasts [17], and recently the daily protein need for athletes has been settled well above the RDA [18]. Interestingly, protein intake is critical also during weight loss in elite athletes [19], especially in weight category sports where rapid weight loss is often achieved through excessive caloric reduction [20]. However, many questions are still open about protein supplementation; for example, the optimal requirement for athletes with different lengths of training experience [21], timing of 
supplementation [22], or different types of protein [23]. Whilst the latter has been recently investigated, the different effects of essential amino acids (EAA) and whey protein on aminoacidemia are still not clear; in this respect, Nakayama and collaborators showed that whey protein can induce a higher level of aminoacidemia compared to an essential amino acid blend [24]. A few final words should be devoted to a new complex chapter in sport nutrition: the inter-individual differences in response to supplements. Recently, there has been a great debate about low, normal and high responders to training [25], both in endurance [26] and resistance training [27,28], but the same approach could be used for sport supplements. Some data about the lack of caffeine's ergogenic effects [29] or about ethnic differences in the response to a New Zealand blackcurrant extract [30] may be explained by some genetic and/or microbiota differences among individuals. All things considered, sport nutrition is a growing, interesting field of research that deserves wider and more strictly-controlled studies in the future.

Funding: This research received no external funding.

Conflicts of Interest: The authors declare no conflict of interest.

\section{References}

1. Paoli, A.; Bianco, A.; Grimaldi, K.A. The ketogenic diet and sport: A possible marriage? Exerc. Sport Sci. Rev. 2015, 43, 153-162. [CrossRef] [PubMed]

2. Murtaza, N.; Burke, L.M.; Vlahovich, N.; Charlesson, B.; O’Neill, H.; Ross, M.L.; Campbell, K.L.; Krause, L.; Morrison, M. The effects of dietary pattern during intensified training on stool microbiota of elite race walkers. Nutrients 2019, 11, 261. [CrossRef] [PubMed]

3. Durkalec-Michalski, K.; Zawieja, E.E.; Zawieja, B.E.; Jurkowska, D.; Buchowski, M.S.; Jeszka, J. Effects of low versus moderate glycemic index diets on aerobic capacity in endurance runners: Three-week randomized controlled crossover trial. Nutrients 2018, 10, 370. [CrossRef] [PubMed]

4. Vlahoyiannis, A.; Aphamis, G.; Andreou, E.; Samoutis, G.; Sakkas, G.K.; Giannaki, C.D. Effects of high vs. Low glycemic index of post-exercise meals on sleep and exercise performance: A randomized, double-blind, counterbalanced polysomnographic study. Nutrients 2018, 10, 1795. [CrossRef] [PubMed]

5. Dennig, H.; Talbott, J.H.; Edwards, H.T.; Dill, D.B. Effect of acidosis and alkalosis upon capacity for work. J. Clin. Investig. 1931, 9, 601-613. [CrossRef] [PubMed]

6. Jones, N.L.; Sutton, J.R.; Taylor, R.; Toews, C.J. Effect of ph on cardiorespiratory and metabolic responses to exercise. J. Appl. Physiol. Respir. Environ. Exerc. Physiol. 1977, 43, 959-964. [CrossRef] [PubMed]

7. Chycki, J.; Golas, A.; Halz, M.; Maszczyk, A.; Toborek, M.; Zajac, A. Chronic ingestion of sodium and potassium bicarbonate, with potassium, magnesium and calcium citrate improves anaerobic performance in elite soccer players. Nutrients 2018, 10, 1610. [CrossRef] [PubMed]

8. Durkalec-Michalski, K.; Zawieja, E.E.; Podgorski, T.; Zawieja, B.E.; Michalowska, P.; Loniewski, I.; Jeszka, J. The effect of a new sodium bicarbonate loading regimen on anaerobic capacity and wrestling performance. Nutrients 2018, 10, 697. [CrossRef] [PubMed]

9. Carr, A.J.; Hopkins, W.G.; Gore, C.J. Effects of acute alkalosis and acidosis on performance: A meta-analysis. Sports Med. 2011, 41, 801-814. [CrossRef] [PubMed]

10. Mujika, I.; Halson, S.; Burke, L.M.; Balague, G.; Farrow, D. An integrated, multifactorial approach to periodization for optimal performance in individual and team sports. Int. J. Sports Physiol. Perform. 2018, 13, 538-561. [CrossRef] [PubMed]

11. Orru, S.; Imperlini, E.; Nigro, E.; Alfieri, A.; Cevenini, A.; Polito, R.; Daniele, A.; Buono, P.; Mancini, A. Role of functional beverages on sport performance and recovery. Nutrients 2018, 10, 1470. [CrossRef] [PubMed]

12. Paoli, A.; Moro, T.; Bosco, G.; Bianco, A.; Grimaldi, K.A.; Camporesi, E.; Mangar, D. Effects of n-3 polyunsaturated fatty acids (omega-3) supplementation on some cardiovascular risk factors with a ketogenic mediterranean diet. Mar. Drugs 2015, 13, 996-1009. [CrossRef] [PubMed]

13. Buckley, C.D.; Gilroy, D.W.; Serhan, C.N. Proresolving lipid mediators and mechanisms in the resolution of acute inflammation. Immunity 2014, 40, 315-327. [CrossRef] [PubMed]

14. Ochi, E.; Tsuchiya, Y. Eicosapentaenoic acid (epa) and docosahexaenoic acid (dha) in muscle damage and function. Nutrients 2018, 10, 552. [CrossRef] [PubMed] 
15. Ballmann, C.; Denney, T.; Beyers, R.J.; Quindry, T.; Romero, M.; Selsby, J.T.; Quindry, J.C. Long-term dietary quercetin enrichment as a cardioprotective countermeasure in mdx mice. Exp. Physiol. 2017, 102, 635-649. [CrossRef] [PubMed]

16. Bazzucchi, I.; Patrizio, F.; Ceci, R.; Duranti, G.; Sgro, P.; Sabatini, S.; Di Luigi, L.; Sacchetti, M.; Felici, F. The effects of quercetin supplementation on eccentric exercise-induced muscle damage. Nutrients 2019, 11, 205. [CrossRef] [PubMed]

17. Bianco, A.; Mammina, C.; Thomas, E.; Bellafiore, M.; Battaglia, G.; Moro, T.; Paoli, A.; Palma, A. Protein supplementation and dietary behaviours of resistance trained men and women attending commercial gyms: A comparative study between the city centre and the suburbs of palermo, Italy. J. Int. Soc. Sports Nutr. 2014, 11, 30. [CrossRef] [PubMed]

18. Phillips, S.M.; Chevalier, S.; Leidy, H.J. Protein "requirements" beyond the rda: Implications for optimizing health. Appl. Physiol. Nutr. Metab. 2016, 41, 565-572. [CrossRef] [PubMed]

19. Hector, A.J.; Phillips, S.M. Protein recommendations for weight loss in elite athletes: A focus on body composition and performance. Int. J. Sport Nutr. Exerc. Metab. 2018, 28, 170-177. [CrossRef] [PubMed]

20. Kondo, E.; Sagayama, H.; Yamada, Y.; Shiose, K.; Osawa, T.; Motonaga, K.; Ouchi, S.; Kamei, A.; Nakajima, K.; Higaki, Y.; et al. Energy deficit required for rapid weight loss in elite collegiate wrestlers. Nutrients 2018, 10, 536. [CrossRef] [PubMed]

21. Paoli, A.; Pacelli, Q.F.; Cancellara, P.; Toniolo, L.; Moro, T.; Canato, M.; Miotti, D.; Neri, M.; Morra, A.; Quadrelli, M.; et al. Protein supplementation does not further increase latissimus dorsi muscle fiber hypertrophy after eight weeks of resistance training in novice subjects, but partially counteracts the fast-to-slow muscle fiber transition. Nutrients 2016, 8, 331. [CrossRef] [PubMed]

22. Kerksick, C.M.; Arent, S.; Schoenfeld, B.J.; Stout, J.R.; Campbell, B.; Wilborn, C.D.; Taylor, L.; Kalman, D.; Smith-Ryan, A.E.; Kreider, R.B.; et al. International society of sports nutrition position stand: Nutrient timing. J. Int. Soc. Sports Nutr. 2017, 14, 33. [CrossRef] [PubMed]

23. Hamarsland, H.; Nordengen, A.L.; Nyvik Aas, S.; Holte, K.; Garthe, I.; Paulsen, G.; Cotter, M.; Borsheim, E.; Benestad, H.B.; Raastad, T. Native whey protein with high levels of leucine results in similar post-exercise muscular anabolic responses as regular whey protein: A randomized controlled trial. J. Int. Soc. Sports Nutr. 2017, 14, 43. [CrossRef] [PubMed]

24. Nakayama, K.; Sanbongi, C.; Ikegami, S. Effects of whey protein hydrolysate ingestion on postprandial aminoacidemia compared with a free amino acid mixture in young men. Nutrients 2018, 10, 507. [CrossRef] [PubMed]

25. Timmons, J.A. Variability in training-induced skeletal muscle adaptation. J. Appl. Physiol. (1985) 2011, 110, 846-853. [CrossRef] [PubMed]

26. Montero, D.; Lundby, C. Refuting the myth of non-response to exercise training: 'Non-responders' do respond to higher dose of training. J. Physiol. 2017, 595, 3377-3387. [CrossRef] [PubMed]

27. Hubal, M.J.; Gordish-Dressman, H.; Thompson, P.D.; Price, T.B.; Hoffman, E.P.; Angelopoulos, T.J.; Gordon, P.M.; Moyna, N.M.; Pescatello, L.S.; Visich, P.S.; et al. Variability in muscle size and strength gain after unilateral resistance training. Med. Sci. Sports Exerc. 2005, 37, 964-972. [PubMed]

28. Stapley, P.J.; McAndrew, D.J.; Walsh, J.A.; Kellis, E.; Mickel, C.; Paoli, A. The "journal of functional morphology and kinesiology" journal club series: Highlights on recent papers in strength and conditioning. J. Funct. Morphol. Kinesiol. 2017, 2, 36. [CrossRef]

29. Marques, A.C.; Jesus, A.A.; Giglio, B.M.; Marini, A.C.; Lobo, P.C.B.; Mota, J.F.; Pimentel, G.D. Acute caffeinated coffee consumption does not improve time trial performance in an 800-m run: A randomized, double-blind, crossover, placebo-controlled study. Nutrients 2018, 10, 657. [CrossRef] [PubMed]

30. Willems, M.E.T.; Parktin, N.; Widjaja, W.; Ajjimaporn, A. Effect of new zealand blackcurrant extract on physiological responses at rest and during brisk walking in southeast asian men: A randomized, double-blind, placebo-controlled, crossover study. Nutrients 2018, 10, 1732. [CrossRef] [PubMed]

(C) 2019 by the author. Licensee MDPI, Basel, Switzerland. This article is an open access article distributed under the terms and conditions of the Creative Commons Attribution (CC BY) license (http:/ / creativecommons.org/licenses/by/4.0/). 